\title{
STUDIES ON L-ORNITHINE FERMENTATION
}

\section{THE BIOSYNTHETIC PATHWAY OF L-ORNITHINE IN MICROCOCCUS GLUTAMICUS*}

\author{
SHIGEZO UDAKA and SHUKUO KINOSHITA \\ Tokyo Research Laboratory, Kyowa Fermentation Industry Company \\ Received for publication November 11, 1958
}

Ornithine is known to be an intermediate metabolite in arginine biosynthesis and, also belongs to the glutamic acid family from confirmation in various microorganisms by isotopic experiments ${ }^{(1,2)}$.

Two synthetic pathways of ornithine have been discovered. One of these involves the direct reduction of the carboxyl group of glutamic acid and the transamination to form ornithine, as known in the case of Neurospora, Torula, and probably of mammals. The equilibrium of the transamination between ornithine and glutamic acid is known to exist far in the formation of glutamic acid(3). Thus, the organism concerned in this study has little possibility to assume this pathway, since a large amount of ornithine and a small amount of $\alpha$-ketoglutaric acid could be accumulated in the medium by this organism as reported in the preceding paper ${ }^{(4)}$.

In $E$. coli, $\mathrm{N}$-acetylglutamic acid** and some other $\mathrm{N}$-acetyl compounds may be precursors of ornithine, as elucidated by Vogel and his coworkers ${ }^{(2)}$. In this paper, a citrulline requiring mutant strain of Micrococcus glutamicus, which accumulates a large amount of L-ornithine ${ }^{(3)}$, has been shown to assume a biosynthetic pathway of ornithine rather similar to that in $E$. coli. One apparent difference noted is that acetylornithinase which has a hydrolytic action on Ac-Orn in E. coli does not exist in this organism.

\section{MATERIAL AND METHODS}

The cells in a vigorous production of ornithine were used throughout this study. Micrococcus glutamicus strain U-1-3 was grown in the following fermentation medium: $10 \%$ glucose, $0.1 \%$ potassium phosphate, $0.03 \%$ $\mathrm{MgSO}_{4} \cdot 7 \mathrm{aq}, 1.0 \% \mathrm{NZ}$-amine, $0.5 \%$ Corn steep liquor. Fermentation was

* This paper was presented at the monthly meeting of the Agricultural Chemical Society of Japan held in July, 1958.

** The following abbreviations are used here: Ac-Glu, N-acetyl-L-glutamic acid; Ac-Orn, $\mathrm{N}^{\alpha}$-acetyl-L-ornithine; AGS, N-acetyl-L-glutamic- $\gamma$-semialdehyde; ATP, adenosine triphosphate; $\mathrm{TPN}^{+}$and $\mathrm{TPNH}$, oxidized and reduced triphosphopyridine nucleotide, respectively; DPN, diphosphopyridine nucleotide; Tris, tris (hydroxymethyl) amino methane; $\mathrm{Pi}$, inorganic phosphate. 
conducted as previously described ${ }^{(3)}$. After 2 days' culture, the cells were collected by centrifugation and washed twice with $0.9 \% \mathrm{NaCl}$ solution and were then suspended in $0.05 \mathrm{~m}$ potassium phosphate buffer, $\mathrm{pH} 7.5$. The cell concentration was adjusted to $100 \mathrm{mg}$ dry weight per $\mathrm{ml}$ by its optical density and this was used as an intact cell suspension. This suspension was further treated by a $9 \mathrm{KC}$ Raytheon sonic oscillator with the addition of a small amount of washed quartz powder for 20 minutes. The cell debris was precipitated by centrifugation at $10,000 \times \mathrm{G}$ and a transparent cell-free extract was obtained. In some experiments, the extract was dialyzed against $0.02 \mathrm{~m}$ potassium phosphate buffer, $\mathrm{pH} 7.5$, using a cellophane dialyser tubing. All operations for the extract were carried out at $0-5^{\circ} \mathrm{C}$.

In aerobic experiments, the reaction mixture was placed in a big test tube (diameter, $24 \mathrm{~mm}$ ) and aerated by a reciprocal shaker at $28^{\circ} \mathrm{C}$. An anaerobic experiment was performed by incubating the reaction mixture in a Thunberg tube in vacuo.

Ornithine was measured colorimetrically by the method of Chinard ${ }^{(5)}$. When Ac-Orn was present in the reaction mixtures, ornithine was determined according to the method of Vogel and Bonner ${ }^{(6)}$. L-Glutamic acid analysis was made manometrically using glutamic decarboxylse preparation obtained from $E$. coli $\mathrm{C}-6^{(7)}$. Protein was measured by a biuret method ${ }^{(8)}$. All spectrophotometric measurements were performed with a Beckman model DU spectrophotometer.

L-Ornithine was the purest product obtained by fermentation. Ac-Orn was at first chemically synthesized ${ }^{(9,10)}$. Later, Ac-Orn which was prepared enzymatically was also used in some experiments. L-Ornithine and Ac-Glu were incubated with cell homogenate and, Ac-Orn thus formed was purified using ion exchange resins. The product melted at $235^{\circ} \mathrm{C}$. Anal. Calculated for $\mathrm{C}_{7} \mathrm{H}_{14} \mathrm{O}_{3} \mathrm{~N}_{2}$ : C, 48.26; H, 8.10; N, 16.08. Found: C, 48.26; H, 8.28; $\mathrm{N}, 16.34$. AGS was prepared as follows: An equimolar amount of Ac-Orn and $\alpha$-ketoglutarate were reacted by an adequate amount of cell homogenate and the cell debris was removed by centrifugation after completion of the reaction. The solution was treated with $\mathrm{H}^{+}$type of Amberite IR-120 to remove amino acids and cations. The acidic effluent was then passed very slowly through $\mathrm{Cl}^{-}$type of Amberite IR-4B to absorb $\alpha$-ketoglutaric acid and anions. The effluent was concentrated in vacuo and treated with active carbon. The solution was concentrated to dryness and a colorless viscous liquid was obtained. It was chromatographically slightly contaminated with other amino acids and organic acids, and its 2, 4-dinitrophenyl hydrazine derivative melted at $208^{\circ} \mathrm{C}^{(11)}$. Anal. Calculated for $\mathrm{C}_{13} \mathrm{H}_{15} \mathrm{O}_{7} \mathrm{~N}_{5}$ : C, 44.19; $\mathrm{H}, 4.28 ; \mathrm{N}, 19.83$. Found: C, 44.08; H, 4.46; N, 19.66. ATP and pyridoxal$5^{\prime}$-phosphate were obtained from Wakamoto Pharmaceutical Co. Coenzyme A and TPN were products of Nutritional Biochemicals Corporation. DPN was purchased from Tokyo Kasei Co. Pyridine nucleotides were reduced chemically by hydrosulfite method ${ }^{(12)}$. NZ-amine, an enzymatic digest of casein, was a product of Sheffield Chemical Company. 


\section{RESULTS}

Experiments with Cell Suspension

The production of ornithine from glutamic acid and other metabolites by the intact cells was tested. As shown in Table 1, the ornithine content

Table 1. Production of ornithine by intact cells

\begin{tabular}{|c|c|c|c|}
\hline \multirow{2}{*}{ Substrate } & \multicolumn{3}{|c|}{ Ornithine produced } \\
\hline & 1 & 3 & 8 hours \\
\hline Glutamate* & $8.5 \mu$ moles & $9.4 \mu$ moles & $17.8 \mu$ moles \\
\hline Acetate & 3.8 & 4.2 & 4.5 \\
\hline +Glutamate & 18.9 & 20.8 & 22.7 \\
\hline Pyruvate & 4.3 & 3.2 & 1.9 \\
\hline +Glutamate & 21.0 & 18.7 & 32.4 \\
\hline Citrate & 1.5 & 2.0 & 1.8 \\
\hline +Glutamate & 10.9 & 18.3 & 22.6 \\
\hline$\alpha$-Ketoglutarate & 2.3 & 3.2 & 1.6 \\
\hline +Glutamate & 14.1 & 17.2 & 21.3 \\
\hline Fumarate & 5.3 & 2.5 & 4.3 \\
\hline +Glutamate & 14.8 & 13.4 & 24.1 \\
\hline Oxalacetate & 9.1 & 7.5 & 13.8 \\
\hline +Glutamate & 11.8 & 17.4 & 31.8 \\
\hline Gluconate & 2.3 & 4.4 & 7.3 \\
\hline +Glutamate & 16.3 & 20.0 & 33.8 \\
\hline Glucose-6-phosphate & 1.6 & 4.6 & 0.0 \\
\hline + Glutamate & 18.9 & 22.4 & 28.0 \\
\hline Glucose & 6.1 & 4.0 & 7.5 \\
\hline +Glutamate & 13.5 & 28.3 & 41.5 \\
\hline$+\mathrm{NH}_{4} \mathrm{Cl}$ & 36.0 & 51.2 & 77.5 \\
\hline$+" \prime$ +Glutamate & 59.8 & 68.9 & 87.0 \\
\hline
\end{tabular}

* All acids were used as sodium salt.

The reaction mixtures contained $350 \mu$ moles of potassium phosphate buffer, $\mathrm{pH} 7.8,10 \mu$ moles of $\mathrm{MgCl}_{2}, 100 \mu$ moles of substrate except for $200 \mu$ moles of $\mathrm{NH}_{4} \mathrm{Cl}$, and $100 \mathrm{mg}$ (as dry matter) of intact cells in a total volume of $5 \mathrm{ml}$. They were incubated with shaking at $28^{\circ} \mathrm{C}$ for the indicated periods.

of the reaction mixture increased considerably with the addition of glutamic acid alone, but did not increase significantly with other compounds except for oxaloacetate. The metabolites which increased the production of ornithine in combination with glutamic acid were mainly glucose, pyruvate, oxaloacetate, and gluconate. It was noted that ornithine was produced aerobically much more efficiently from glucose and ammonium chloride than from 
glucose and glutamic acid. This could be explained by the role of ammonium ion in accelerating the glucose degradation and enhancing its utilization, as reported in the study of glutamic acid fermentation ${ }^{(7)}$.

Anaerobic production of ornithine was attempted with the cell homogenate; i. e., the sonicate containing the cell debris. Various metabolic compounds and ATP were tested solely and in various combinations as the substrate for the anaerobic formation of ornithine. Only glutamic acid was found effective to increase ornithine production and no apparent influence was obtained by the other compounds. These results are favorable to the assumption that glutamic acid is a precursor of ornithine. Since clear-cut enzymatic reactions were obtained in the experiments with the cell free extract, no further study was attempted with the intact cell suspension or cell homogenate.

\section{Experiments with Cell Free Extract}

(a) Acetylation of Glutamic Acid.

The findings that Ac-Glu was the substrate for phosphorylation and reduction (sections $\mathrm{b}$ and $\mathrm{d}$ ) and for transacetylation (section e) strongly suggested the acetylation of glutamic acid as the first step reaction of ornithine synthesis from glutamic acid. In fact, the organic acid which had the same Rf value of Ac-Glu was noted in the broth at a later stage of fermentation by paper chromatography. However, a trial run to show the acetylation of glutamic acid by cell free extract was not successful. The enzymatic acetylation of glutamic acid was demonstrated in E. coli by Maas et al. ${ }^{(13)}$ and similar experimental conditions were adopted to this organism in order to show the enzymic activity, using acetyl phosphate or acetate plus ATP as an acetyl donor. Analytical data showed no increase in the Ac-Glu content of the reaction mixture. The mechanism of the acetylation of glutamic acid is still a problem that remains unsolved.

(b) Phosphorylation of Ac-Glu.

The presence of the enzyme which catalyzes the phosphorylation of AcGlu and the reduction of its phosphorylated intermediate has been strongly suggested and is described below.

An enzymic phosphorylation of Ac-Glu was found to occur in the extract of this organism. It appears to catalyze reaction. 1.

$$
\text { Ac-Glu }+ \text { ATP } \underset{\mathrm{Mg}^{++}}{\rightleftarrows}[\mathrm{N} \text {-acetyl- } \gamma \text {-glutamyl phosphate + ADP }]
$$

Although its equilibrium is unfavorable for the accumulation of the new compound, the reaction could be followed when hydroxylamine was used as a traping agent of the compound formed, as it has been originally performed with acetyl phosphate ${ }^{(14)}$. The enzymatic activity using the conventional hydroxamic method, is shown in Table 2. Since the omission of Ac-Glu or ATP or $\mathrm{Mg}$ ion from the reaction mixtures resulted in a marked decrease in hydroxamate formation, the reaction most likely proceeds according to 
Table 2. Phosphorylation of Ac-Glu.

\begin{tabular}{l|ccc}
\hline \multirow{2}{*}{ Composition } & \multicolumn{3}{|c}{ Hydroxamate formed* } \\
\cline { 2 - 4 } & 0 & 20 min. & 4 hours \\
\hline Complete & .068 & .174 & .890 \\
- ATP & .041 & .042 & .039 \\
$-\mathrm{Ac}-\mathrm{Glu}$ & .039 & .035 & .038 \\
$-\mathrm{MgCl}_{2}$ & .045 & .095 & .505 \\
\hline
\end{tabular}

* Optical density at $540 \mathrm{~m} \mu$.

The reaction mixures contained $50 \mu$ moles of sodium Ac-Glu, $10 \mu$ moles of ATP, $10 \mu$ moles of $\mathrm{MgCl}_{2}, 200 \mu$ moles of hydroxylamine hydrochloride which was brought to $\mathrm{pH} 8$ with tris base and $0.1 \mathrm{ml}(1.4 \mathrm{mg}$ of protein) of cell free extract in a total volume of $1.0 \mathrm{ml}$. They were incubated at $28^{\circ} \mathrm{C}$ and, $1 \mathrm{ml}$ of the samples diluted 3 times was treated with $1 \mathrm{ml}$ of $3 \mathrm{~N} \mathrm{HCl}, 1 \mathrm{ml}$ of $12 \%$ trichloroacetic acid, and $1 \mathrm{ml}$ of $5 \% \mathrm{FeCl}_{3} \cdot 6 \mathrm{aq}$ in $0.1 \mathrm{~N} \mathrm{HCl}$, then the optical density of the supernatant was measured.

equation 1 . The decomposition product of ATP and the stoichiometry of the reaction were not determined.

(c) Oxidation of AGS.

As shown in Fig. 1, TPN was reduced in the presence of AGS and potassium phosphate or sodium phosphate by the dialyzed cell free extract. The reaction showed a strong dependence on $\mathrm{Pi}$ and, the oxidation of TPNH in the reverse reaction which is described in the following section was severely inhibited by $\mathrm{Pi}$. These observations strongly suggest that the reaction proceeds according to equations 2 and 3 , and the hypothetical compound, $\mathrm{N}$-acetyl- $\boldsymbol{\gamma}$-glutamyl phosphate,

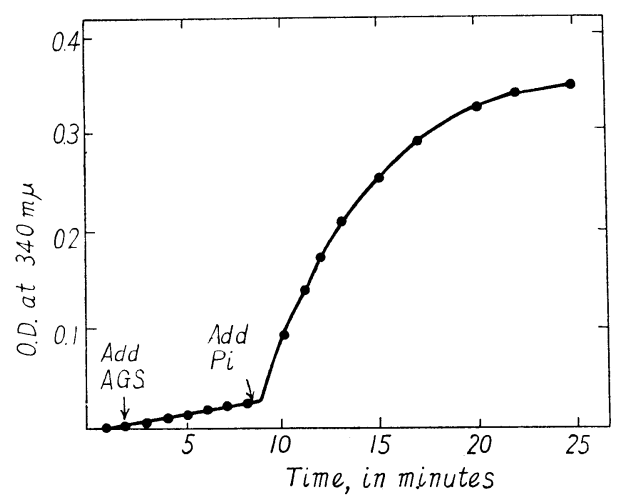

Fig. 1. Reduction of TPN by AGS. The complete system contained about 30 $\mu$ moles of AGS, $0.25 \mu$ moles of TPN, 100 $\mu$ moles of tris buffer, $\mathrm{pH} 7.5,50 \mu$ moles of potassium phosphate buffer (as $\mathrm{Pi}$ ), $\mathrm{pH}$ 7.5 , and $0.02 \mathrm{ml}(0.6 \mathrm{mg}$ protein) of dialyzed extract in a total volume of $1.5 \mathrm{ml}$ and were incubated at room temperature. does exist as an intermediate metabolite.
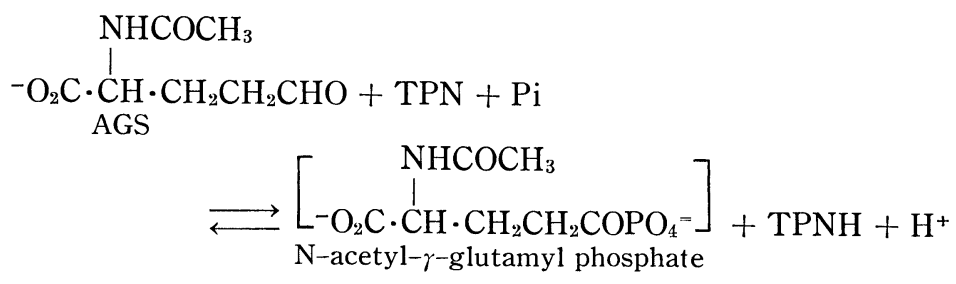


$$
\text { Ac-Glu } \underset{\mathrm{Mg}^{++}}{\stackrel{\text { ATP }}{\rightleftarrows}}[\mathrm{N}-\text { Acetyl- } \gamma \text {-glutamyl phosphate }] \stackrel{\text { TPN }}{\rightleftarrows} \text { AGS }
$$

The formation of hydroxamic acid was noted from the reaction mixture of TPN reduction with the addition of hydroxylamine; this also suggests the formation of an acyl phosphate.

(d) Reduction of Ac-Glu.

If reaction 3 could occur by the cell free extract as the result of a reaction sequence of 1 and 2 , the oxidation of TPNH was expected to take place in a reaction mixture containing the $\mathrm{N}$-acetyl- $\gamma$-glutamyl phosphate generating-system. Data supporting this assumption is presented in Fig. 2. In

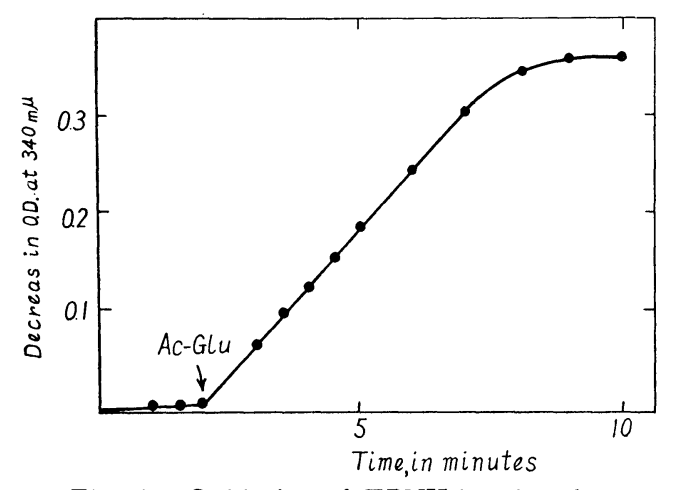

Fig. 2. Oxidation of TPNH by phosphorylated compound of Ac-Glu.

The complete system contained $50 \mu$ moles of sodium Ac-Glu, $4 \mu$ moles of ATP, $0.06 \mu$ moles of TPNH, $2 \mu$ moles of $\mathrm{MgCl}_{2}, 100 \mu$ moles of tris buffer, $\mathrm{pH} 7.5$, and $0.01 \mathrm{ml}$ $(0.09 \mathrm{mg}$ protein) of dialyzed extract in a total volume of $1.7 \mathrm{ml}$. The incubation was carried out at room temperature. control tests, TPNH was oxidized only very slowly in the absence of any one component; i.e., Ac-Glu, ATP, and $\mathrm{MgCl}_{2}$. In the oxidation of TPNH, the reaction proceeded more rapidly at $\mathrm{pH}$ in the vicinity of 7 than at a higher $\mathrm{pH}$ when tris buffer was used, and the rate of the reaction did not markedly fall even at $\mathrm{pH}$ 8.7. The specificity of the enzyme for pyridine nucleotides was not determined, since DPNH was very rapidly oxidized without added substrate by a well dialyzed extract and the study on the nature of the DPNH oxidation has not been elaborated. It is conceivable that TPN acts as a cofactor for the enzyme concerned within the cell.

(e) Transamination between AGS and Glutamic Acid.

Ac-Orn was reacted with $\alpha$-ketoglutaric acid by the extract, and one of the main products was isolated and identified as AGS, as described in the section of material and method. Another main product, glutamic acid changed in part to Ac-Glu as the result of transacetylation with Ac-Orn (refer the following section). Although an ammonium sulfate fractionation of the extract caused the partial separation of the cofactor of the enzyme which is responsible for the transamination, the enzyme activity of transacetylation remained in the same fraction (reaction 4). 


$$
\begin{aligned}
& \text { Pyridoxal } \\
& \text { AGS }+ \text { Glutamic acid } \stackrel{\text { phosphate }}{\longleftarrow} \text { Ac-Orn }+\alpha \text {-Ketoglutaric acid } \\
& \begin{aligned}
\uparrow \downarrow \text { Ac-Orn } \\
\text { Ac-Glu }+ \text { Ornithine }
\end{aligned}
\end{aligned}
$$

Table 3. Transamination between AGS and glutamic acid.

\begin{tabular}{c|c|cc|cc}
\hline \multirow{2}{*}{ Substrate } & $\begin{array}{l}\text { Pyridoxal- } \\
\text { phosphate }\end{array}$ & \multicolumn{2}{|c|}{3 hours } & \multicolumn{2}{c}{15 hours } \\
\cline { 3 - 6 } & Ornithine & Glutamate & Ornithine & Glutamate \\
\hline \multirow{2}{*}{ Ac-Orn } & + & $\mu$ moles & $\mu$ moles & $\mu$ moles & $\mu$ moles \\
Ac-Orn $+\alpha-$ Ketoglutarate & + & 3.8 & 8.2 & 4.2 & 9.8 \\
$" \quad+\quad "$ & - & 2.1 & 1.5 & - & - \\
AGS & + & 0.2 & - & - & - \\
AGS+Glutamate & + & - & - & 3.2 & 13.2 \\
\hline
\end{tabular}

The reaction mixtures contained $50 \mu$ moles of potassium phosphate buffer, $\mathrm{pH}$ $7.8,20 \mu$ moles of substrate, $10 \gamma$ of pyridoxal $-5^{\prime}$-phosphate as indicated, $0.2 \mathrm{ml}$ $(1.1 \mathrm{mg}$ protein) of an ammonium sulfate fractionated preparation of extract (55-70\% saturated fraction of precipitants) in a total volume of $1.0 \mathrm{ml}$ and were incubated at $37^{\circ} \mathrm{C}$ for periods of 3 hours and 15 hours.

As shown in Table 3, a reactivation of fractionated enzyme by pyridoxal5 -phosphate is apparently observed. The optimal $\mathrm{pH}$ for this reaction was approximately 7.5 (Fig. 3). As for specificity of the enzyme to substrates, major amino acids, 15 kinds, were tested to ascertain whether or not these amino acids could be the amino donor to AGS. A rough paper chromatographic survey revealed that none of the amino acids formed Ac-Orn in an amount comparable to glutamic acid as an amino donor. Furthermore, no apparent transamination was shown between Ac-Orn and pyruvate or oxaloacetate. The accurate determination of an equilibrium constant of the reaction was not possible, because a side reaction occurred and AGS could not be measured exactly. A very approximate equilibrium constant, i.e., 0.1, was obtained from the data in Table 3.

(f) Transacetylation between Ac-Orn and Glutamic Acid.

The enzyme which catalizes reaction 5 was strongly assumed to exist.

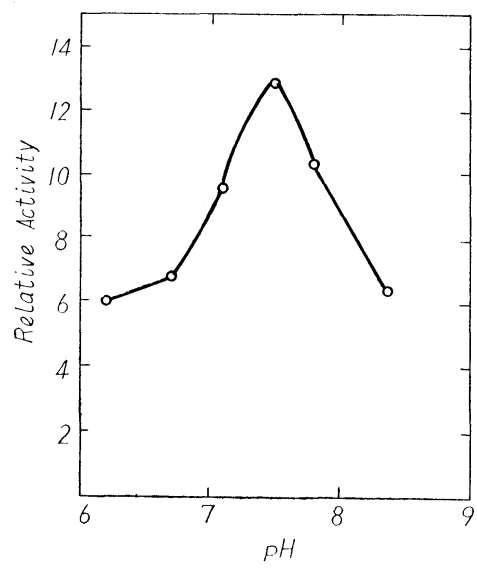

Fig. 3. PH curve of transaminase activity.

The conditions were the same as the complete system of Table 3 , except that $\mathrm{pH}$ of the buffer was varied. Ordinate indicates, in $\mu$ moles, the amount of ornithine plus glutamic acid formed. 


$$
\text { Ac-Orn }+ \text { Glutamic acid } \rightleftarrows \text { Ornithine }+ \text { Ac-Glu }
$$

Although various kinds of transacetylases have already been reported, the enzyme which catalizes to transfer the acetyl group from an acetylated amino acid to the other amino acid is yet beyond the limits of our knowledge. As shown in Table 4, the enzyme acts exclusively as an acetyl transferase

Table 4. Transacetylation between Ac-Orn and glutamic acid.

\begin{tabular}{|c|c|c|c|}
\hline \multirow{2}{*}{ Substrate } & \multicolumn{2}{|c|}{ Ornithine* } & \multirow{2}{*}{$\begin{array}{c}\text { Glutamic acid* } \\
15 \text { hours }\end{array}$} \\
\hline & 3 & 15 hours & \\
\hline Ac-Orn & $\stackrel{\mu \text { moles }}{-}$ & $\begin{array}{l}\mu \text { moles } \\
0.3\end{array}$ & $\mu$ moles \\
\hline Ac-Orn +L-Glutamate & 5.2 & 7.7 & 13.0 \\
\hline +L-Aspartate & 0.5 & - & - \\
\hline +L-Alanine & 0.6 & - & - \\
\hline$" \quad+\mathrm{L}$-Arginine & 0.1 & - & - \\
\hline Ac-Glu & - & - & 0.1 \\
\hline Ac-Glu +L-Ornithine & - & 7.8 & 13.1 \\
\hline
\end{tabular}

* Blank of substrate was subtracted from the values obtained.

The reaction mixtures contained $50 \mu$ moles of potassium phosphate buffer, $\mathrm{pH} 7.0,20 \mu$ moles of substrate (sodium salt of acidic amino acid was used), and $0.1 \mathrm{ml}(0.7 \mathrm{mg}$ protein) of dialyzed extract in a total volume of $1.0 \mathrm{ml}$, and were incubated at $37^{\circ} \mathrm{C}$.

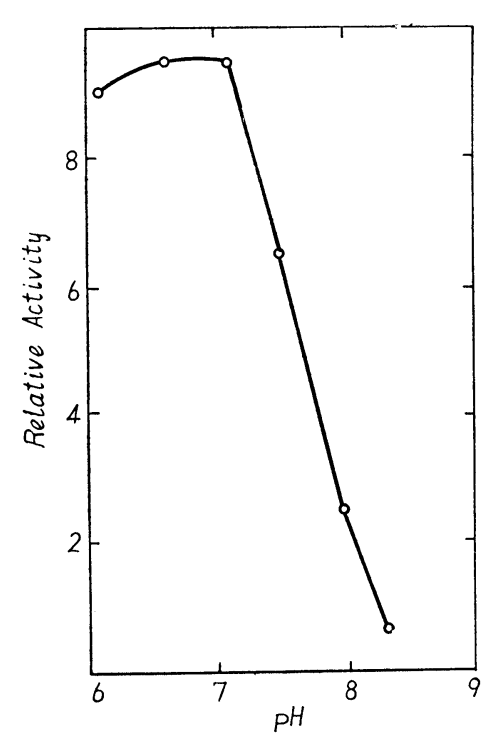

and has no hydrolytic action on Ac-Orn and Ac-Glu. A number of amino acids were tested as a possible acetyl acceptor for Ac-Orn among which the only active amino acid was found to be glutamic acid. Fig. 4 shows the $\mathrm{pH}$ curve of activity of the enzyme. The optimal $\mathrm{pH}$ was about 7 and activity fell rather sharply at a higher $\mathrm{pH}$. An equilibrium was reached at the same proportion of reactants from either side of reaction 5 . The equilibrium

Fig. 4. PH curve of transacetylase activity. The conditions were the same as those indicated in the legend below table 4, adding monosodium glutamate as an acetyl acceptor, except that $\mathrm{pH}$ of the buffer was varied. Ordinate shows the amount of ornithine formed, in $\mu$ moles. 
constant thus obtained was 0.35 (Table 4). Coenzyme A was a possible cofactor of the enzyme. However, treatment of the dialyzed extract with an ion exchange resin, Dowex-1, according to the method of Lipmann et al. ${ }^{(15)}$ as a procedure to remove coenzyme A caused a little decrease in its activity which was not influenced by either the addition of coenzyme A or the boiled extract of the enzyme. Thus, it appears that the acetyl exchange between amino acids is not coenzyme A-dependent, as recognized in the transacetylation between aromatic amines ${ }^{(16)}$. The elucidation of the exact nature of the enzyme which was concerned with reaction 5 awaits futher study on purified preparations.

\section{DISCUSSION}

The results obtained in this study can be summarized in Fig. 5. It may be noted that a cycle of reactions is formed with acetylated compounds. Acetylation of amino radical of glutamic acid may be considered to prevent

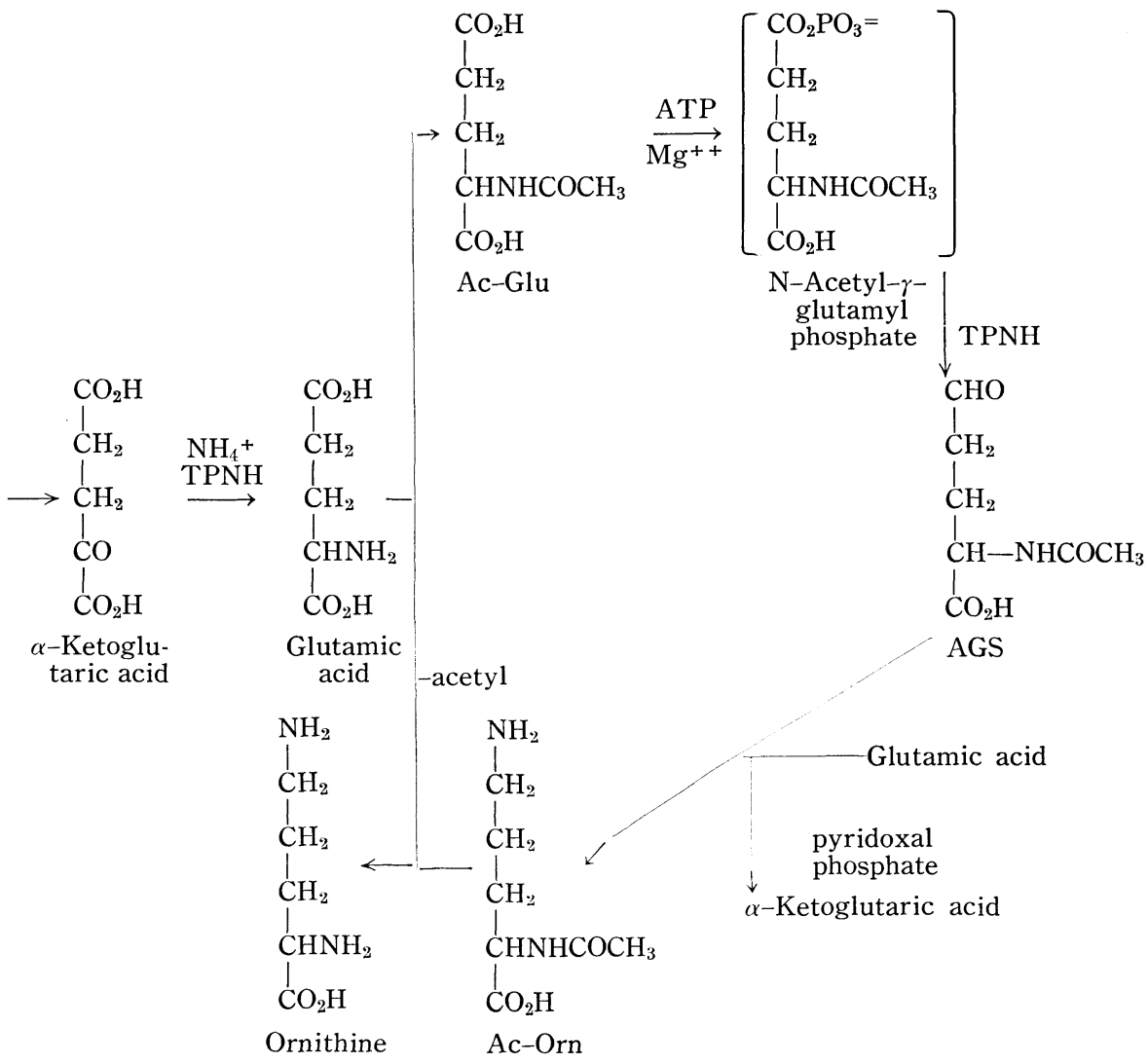

Fig. 5. Proposed biosynthetic pathway of ornithine in Micrococcus glutamicus. 
the ring formation of the reduced forms of glutamic acid, as pointed out by Davis $^{(1)}$. The fact that glutamic acid is a necessary acceptor compound of acetyl radical in the process of the formation of ornithine from Ac-Orn indicates the advantageous use of acetyl radical. In other words, if ornithine is formed by the action of acetylornithinase as in E. coli, extra energy for the acetylation of glutamic acid would be necessary to produce and accumulate ornithine in a large amount. Thus, it might be considered that this pathway makes the efficient production of ornithine possible.

From the metabolic scheme shown in Fig. 5, one mole each of ATP, TPNH and glutamic acid as the amino donor were the necessary components for the conversion of one mole of glutamic acid to one mole of ornithine. Therefore, a very efficient formation of ornithine from glucose strongly suggests that TPNH and ATP generating systems of the cell are very active and the couplings of the reactions are quite smooth. A possible explanation for the aerobic production of ornithine is that the oxidative chain of TPNH to molecular oxygen is very weak, as discussed in the previous paper concerning the glutamic acid fermentation. Moreover, the involvement of ATP in this ornithine fermentation is noteworthy.

In $E$. coli, the biosynthetic pathway of ornithine similar to that of Micrococcus glutamicus have been revealed by Vogel and his coworkers ${ }^{(2,6,11)}$. However, they have so far not shown the enzyme which mediates the reduction of Ac-Glu. In this paper, fairly strong evidences concerning the enzymes of ornithine biosynthesis from glutamic acid in M. glutamicus have been presented. A further evidence supporting this pathway is that a mutant strain which requires ornithine or citrulline or arginine is also grown on the medium containing Ac-Orn or AGS. The reduction of the derivative of glutamic acid is proved to be similar to the reactions of aspartic acid, which were shown by Black and Wright ${ }^{(17,18)}$.

The lack of acetylornithinase and the presence of transacetylase activity in $M$. glutamicus presents a question worth consideration,- -whether or not this phenemenon is unique in bacteria. Since Vogel and Bonner indicated that the strains of Enterobacteriaceae have acetylornithinase activity but Bacillus does not possess such activity, several strains of Bacillus were tested for their transacetylase activity between acetyl derivatives of ornithine and glutamic acid. None of the bacteria tested showed the enzyme activity studied.

\section{SUMMARY}

The enzymatic studies and some experiments with intact cells have been made on the biosynthetic pathway of L-ornithine in Micrococcus glutamicus. The pathway thus revealed is as follows: N-Acetylglutamic acid, which is probably formed via glutamic acid, is phosphorylated and reduced to form $\mathrm{N}$-acetylglutamic- $\gamma$-semialdehyde. $\mathrm{N}$-Acetylornithine is produced as the 
result of transamination between $\mathrm{N}$-acetylglutamic- $\gamma$-semialdehyde and glutamic acid, and it is then deacetylated by the transfer of its acetyl group to glutamic acid, forming ornithine. The last-mentioned reaction seemed to be catalized by a new transacetylase. The conceivable relationship between these results and the efficient production of ornithine in the mutant of $M$. glutamicus has been discussed.

\section{ACKNOWLEDGEMENTS}

The authors are indebted to Mr. K. Tomizawa for his technical assistance.

\section{REFERENCES}

(1) Davis, B. D.: Advances in Enzymology, 16, 247 (1955).

(2) Vogel, H. J.: "Symposium on Amino Acid Metabolism", edited by McElroy and Glass, the Johns Hopkins Press, p. 335 (1955).

(3) Fincham, J. R. S.: Biochem. J. 53, 313 (1953).

(4) Kinoshita, S., Nakayama, K. and Udaka, S.: J. Gen. Appl. Microbiol. (Japan) 3, 276 (1957).

(5) Chinard, F. P.: J. Biol. Chem., 199, 91 (1952).

(6) Vogel, H. J. and Bonner, D. M.: J. Biol. Chem., 218, 97 (1956).

( 7 ) Kinoshita, S., Tanaka, K., Udaka, S. and AKITA, S.: Proceedings of Intern. Symposium on Enz. Chem., Vol. 2, 464 (1957).

(8) Henry, R. J., Sobel, C. and Berkman, S.: Anal. Chem., 29, 1491 (1957).

(9) Harris, J. I. and Work, T. S.: Biochem. J., 46, 582 (1950).

(10) Neuberger, A. and SANGer, F.: ibid, 37, 515 (1943).

(11) Vogel, H. J.: Proc. Natl. Acad. Sci. U. S., 39, 578 (1953).

(12) Kaplan, N. O., Colowick, S. P. and Neufeld, E. F.: J. Biol. Chem., 195, 107 (1952).

(13) Maas, W. K., Novelli, G. D. and Lipmann, F.: Proc. Natl. Acad. Sci. U. S., 39, 1004 (1953).

(14) LipmanN, F.: Advances in Enzymology, 6, 231 (1946).

(15) Stadtman, E. R., Novelli, G. D. and Lipmann, F.: J. Biol. Chem., 191, 365 (1951).

(16) Bessman, S. P. and Lipmann, F.: Arch. Biochem. Biophys., 46, 252 (1953).

(17) Black, S. and Wright, N. G.: J. Biol. Chem., 213, 27 (1955).

(18) Black, S. and Wright, N. G.: ibid, 213, 39 (1955). 